\title{
Soluble A $\beta$ Promotes Wild-Type Tau Pathology In Vivo
}

\author{
Meredith A. Chabrier, ${ }^{\star}$ Mathew Blurton-Jones, ${ }^{\star}$ Andranik A. Agazaryan, Joy L. Nerhus, Hilda Martinez-Coria, \\ and Frank M. LaFerla \\ Department of Neurobiology and Behavior, Institute for Memory Impairment and Neurological Disorders, and Sue and Bill Gross Stem Cell Research \\ Center, University of California Irvine, Irvine, California 92697
}

Growing evidence suggests that soluble $\mathrm{A} \beta$ species can drive Alzheimer disease (AD) pathogenesis by inducing a cascade of events including tau hyperphosphorylation, proteasome impairment, and synaptic dysfunction. However, these studies have relied largely on in vitro approaches to examine the role of soluble $\mathrm{A} \beta$ in $\mathrm{AD}$. In particular, it remains unknown whether soluble $\mathrm{A} \beta$ oligomers can facilitate the development of human wild-type tau pathology in vivo. To address this question, we developed a novel transgenic model that expresses low levels of APP with the Arctic familial AD mutation to enhance soluble A $\beta$ oligomer formation in conjunction with wild-type human tau. Using a genetic approach, we show that reduction of $\beta$-site APP cleaving enzyme (BACE) in these ArcTau mice decreases soluble $\mathrm{A} \beta$ oligomers, rescues cognition, and, more importantly, reduces tau accumulation and phosphorylation. Notably, BACE reduction decreases the postsynaptic mislocalization of tau in ArcTau mice and reduces the association between NMDA receptors and PSD-95. These studies provide critical in vivo evidence for a strong mechanistic link between soluble $\mathrm{A} \beta$, wild-type tau, and synaptic pathology.

\section{Introduction}

Alzheimer disease $(\mathrm{AD})$ is characterized by the accumulation of two hallmark pathologies, $\mathrm{A} \beta$ plaques and neurofibrillary tangles (Querfurth and LaFerla, 2010). Though studies show that $\mathrm{A} \beta$ promotes tau pathology in vitro, a key question that remains is whether soluble $\mathrm{A} \beta$ species can promote the accumulation and phosphorylation of wild-type tau in vivo.

The past several years of research have revealed an important role for soluble, oligomeric $A \beta$ in cognitive and physiological dysfunction (Glabe, 2008). A $\beta$ oligomers have been detected in both human $\mathrm{AD}$ brain and transgenic mouse models of $\mathrm{AD}$ and correlate better with disease progression than insoluble fibrillar plaques (McLean et al., 1999; Näslund et al., 2000; Lacor et al., 2004; Billings et al., 2005; Lesné et al., 2006). Interestingly, $A \beta$ oligomers can induce tau mislocalization and phosphorylation in vitro, providing intriguing evidence that soluble $\mathrm{A} \beta$ modulates the development of tau pathology (Deshpande et al., 2006; Zempel et al., 2010). However, few studies have examined whether soluble $\mathrm{A} \beta$ oligomers influence wild-type human tau pathology in vivo.

To further investigate this question, we designed a doubletransgenic mouse model that produces low levels of Arctic mutant $\mathrm{A} \beta(\mathrm{E} 22 \mathrm{G})$ to preferentially drive the production of soluble

\footnotetext{
Received Jan. 12, 2012; revised Aug. 17, 2012; accepted Sept. 11, 2012.

Author contributions: M.A.C., M.B.-J., and F.M.L. designed research; M.A.C., M.B.-J., A.A.A., J.L.N., and H.M.-C. performed research; M.A.C., M.B.-J., A.A.A., and H.M.-C. analyzed data; M.A.C., M.B.-J., and F.M.L. wrote the paper.

This work was supported by NIH Grants PPG AG00538 and AG027544 (to F.M.L.) and AG029378 and AG16573 (to M.B.-J,), and NIA Grant F31AG039968 (to M.A.C.). We thank Drs. Charles Glabe and Peter Davies for antibodies and Drs. Lars Lannfelt and Michael Vitek for Arctic/Swedish APP and 4R/2N hTau cDNAs. We also thank Adam Pabst for technical assistance. We thank the University of California, Irvine, Transgenic Mouse Facility and Tom Fielder for producing the transgenic founders of the ArcTau line.

*M.A.C. and M.B.-J. contributed equally to this work.

The authors declare no competing financial interests.

Correspondence should be addressed to Dr. Frank M. LaFerla, Department of Neurobiology and Behavior, University of California, Irvine, Irvine, CA 92697-4545. E-mail: laferla@uci.edu.

DOI:10.1523/JNEUROSCI.0172-12.2012

Copyright $\odot 2012$ the authors $\quad 0270-6474 / 12 / 3217345-06 \$ 15.00 / 0$
}

oligomers and protofibrils without producing insoluble $\mathrm{A} \beta$ fibrils. By combining Arctic $A \beta$ with the expression of wild-type human tau, this new model provides a unique tool to examine the effects of soluble, near physiological levels of oligomeric $\mathrm{A} \beta$ on tau pathology and cognition. To examine this question, hemizygous ArcTau mice were crossed with heterozygous BACE knockout $\left(B A C E^{+/-}\right)$mice. The resulting $\operatorname{ArcTau}^{+} / B A C E^{+/-}$mice were then compared with $A r c T_{a u}{ }^{+} / B A C E^{+/+}$littermates. As expected, heterozygous deletion of BACE reduces soluble $A \beta$ and $\mathrm{A} \beta$ oligomers. More importantly, the reduction in soluble $\mathrm{A} \beta$ oligomers is accompanied by a decrease in human tau pathology, including reduced association of tau with PSD-95, and a rescue of learning and memory deficits. Our data therefore indicate that soluble $\mathrm{A} \beta$, particularly soluble $\mathrm{A} \beta$ fibrillar oligomers, facilitate wild-type tau pathology in vivo. Importantly the reduction in soluble $A \beta$ and tau pathology are accompanied by improved cognition. Thus, soluble $A \beta$ fibrillar oligomers represent a viable therapeutic target for early disease modification.

\section{Materials and Methods}

Generation of ArcTau transgenic mice. APP and tau constructs were subcloned into the Thy1.2 expression cassette via homologous recombination (In-Fusion; Clonetech). APP695 with Arctic and Swedish mutations and wild-type human 2N/4R Tau cDNAs [gifts from Drs. Lars Lannfelt (Uppsala University, Uppsala, Sweden) and Michael Vitek (Duke University, Durham, NC)] were amplified by proof-checking PCR using primers with $15 \mathrm{bp}$ homology to the insertion site and a Kozac sequence: APP forward: $5^{\prime}$ GCGTCGACGTGGCTAGCCACCATGCTGCCCGGTTT-3' ${ }^{\prime}$ and APP reverse: 5'-CGAGAACCGCGGAATCGATCTAGTTCTGCATCTGCT CAAAGAAC-3', Tau forward: 5' -GCGTCGACGTGGCTAGCCACCATGGCTGAGCCCCGC-3' and Tau reverse: 5'-CGAGAACCGCGGAATCGATTCACAAACCCTGCTTGGCC-3'. PCR products and linearized Thy1.2 plasmid were purified by gel extraction and the In-fusion reaction performed. Targeting cassettes were liberated from sequence-verified clones, purified by gel extraction, and co-microinjected into the pronuclei of singlecell C57BL6 embryos by the UC Irvine Transgenic Mouse Facility. 
A

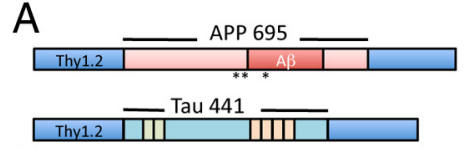

B

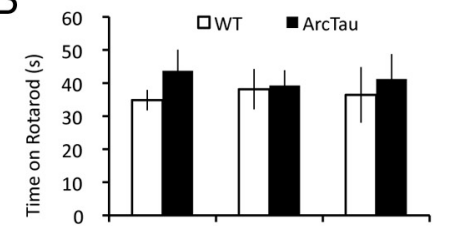

Day1

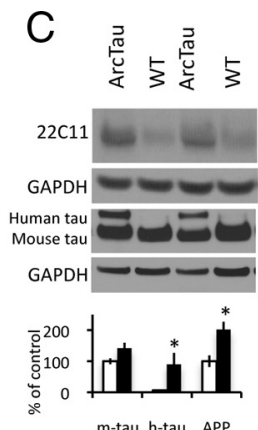

m-tau h-tau APP

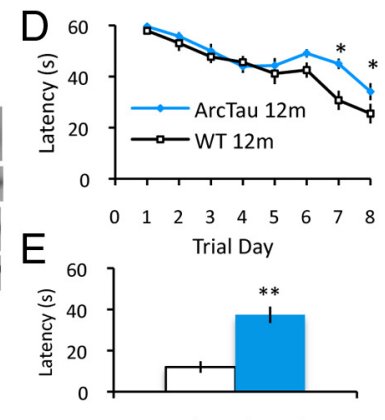

24-hr Probe Trial
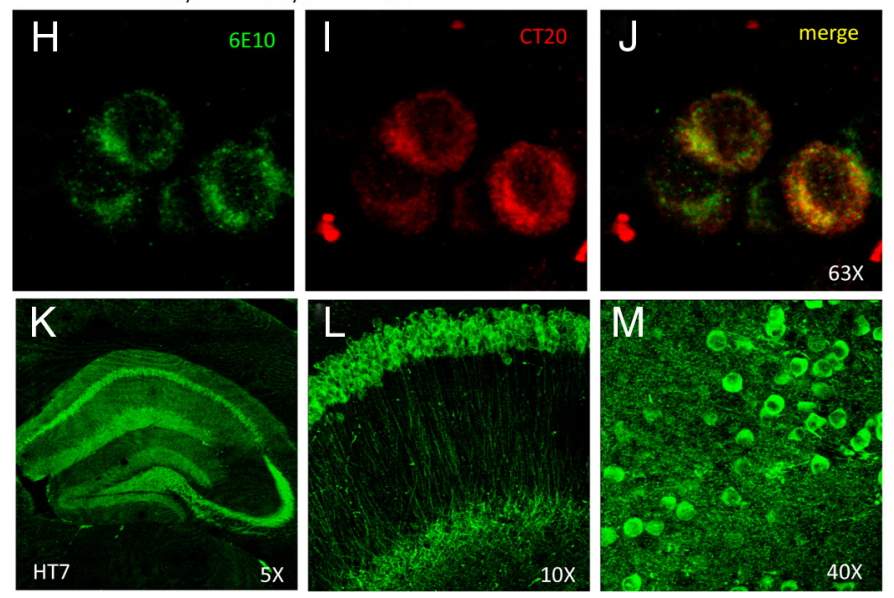

$\mathrm{F}$
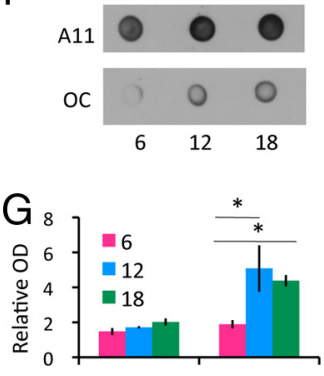

A11

OC
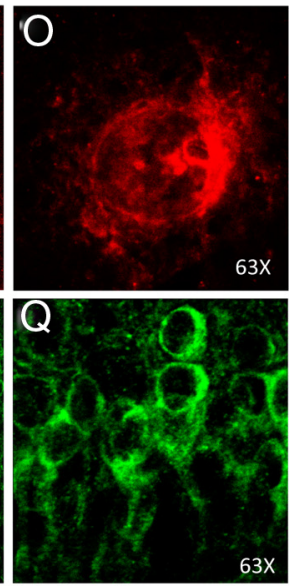

Figure 1. ArcTau mice develop age-related Alzheimer-like pathology and cognitive decline. A, Schematic depiction of human APP and tau transgenes co-microinjected to produce ArcTau transgenic mice. B, ArcTau mice do not display motor deficits at 15 months, as shown by the average time spent on Rotarod compared with WT. C, ArcTau transgenic mice express twofold higher levels of APP (22C11 antibody) and equivalentlevels of human and endogenous mouse tau (Tau46antibody). D. Twelve-month-old ArcTau mice and WT littermate controls were trained in the Morris water maze for $8 \mathrm{~d}$. ArcTau mice performed significantly worse on days 7 and 8 of acquisition. $E$, ArcTau mice also exhibited poor memory for the platform's former location, as evidenced by significantly longer latencies in a $24 \mathrm{~h}$ probe trial. $F$, ArcTau mice show a significant increase in $\mathrm{OC}+$ fibrillar oligomers at 12 months. G, Representative dot blot of ArcTau half-brain samples at 6,12 , and 18 months. $\boldsymbol{H}-\boldsymbol{J}$, Histological analysis at 6 months reveals intraneuronal $A \beta$-like pathology. Full-length APP and A $\beta$ is shown in green $(\boldsymbol{H})$ and $($ terminus of $A P P$ is stained in red $(\boldsymbol{I})$; thus, $A \beta$ is detected by green-only puncta in the merge $(\boldsymbol{J})$. $\boldsymbol{K}-\boldsymbol{M}$, Wild-type total htau $(H T 7)$ is evident throughout the hippocampus $(\boldsymbol{K})$, specifically $\mathbf{C A 1}(\boldsymbol{L})$, and the cortex $(\boldsymbol{M})$ at 6 months. $\boldsymbol{N}, \mathbf{O}$, Rare diffuse plaques only begin to appear at 18 months (subiculum shown). $\boldsymbol{P}, \boldsymbol{Q}$, Hyperphosphorylated (PHF + ) somatodendritic wild-type tau is detected in the CA1 at 18 months. $N=8-10$ per group; ${ }^{*} p<0.05,{ }^{* *} p<0.01$. Error bars represent \pm SEM.

Transgenic genotyping and breeding. All animal procedures were performed in strict accordance with NIH and University of California guidelines. Mice were housed on a $12 \mathrm{~h} / 12 \mathrm{~h}$ light/dark schedule with ad libitum food and water. Transgenic mice were identified by tail PCR, and nontransgenic littermate controls were generated by crossing heterozygous transgenics with wild-type C57BL6 mice (Jax Laboratories). Genotyping demonstrated $100 \%$ coinheritance of APP and tau transgenes in all three founder lines, suggesting cointegration of the two transgenes, as previously observed (Oddo et al., 2003). Hemizygous ArcTau mice were crossed with heterozygous BACE knock-out mice (Roberds et al., 2001) to produce three experimental groups: ArcTau/BACE ${ }^{+/-}$, ArcTaul $B A C E^{+/+}$, and $W T / B A C E^{+/-}$.

Morris water maze. Hippocampal-dependent learning and memory was examined by a blinded observer, using the Morris water maze (MWM) following standard protocols (Billings et al., 2005). Briefly, male and female 15-month-old animals were habituated to a $1-\mathrm{m}$ diameter circular pool filled with opaque water maintained at $29^{\circ} \mathrm{C}$. During the $8 \mathrm{~d}$ of training, mice were placed into the pool and allowed to find a submerged escape platform ( 4 trials/d). On the ninth day, the platform was removed to assess memory retention for the former platform location.

Tissue processing and biochemical analysis. Mice were killed by Nembutal overdose and cardiac perfusion with $0.01 \mathrm{M}$ PBS. Brains were removed and cut along the sagittal midline. Half the brain was frozen on dry ice for subsequent biochemical analysis and half was fixed in $4 \%$ paraformaldehyde ( $\mathrm{pH} 7.4,48 \mathrm{~h}$ ). Fixed half-brains were cut coronally on a Vibratome $(50 \mu \mathrm{m})$ and stored in PBS with $0.02 \% \mathrm{NaN}_{3}$ at $4^{\circ} \mathrm{C}$. Half brains (excluding cerebellum) were processed to isolate soluble and insoluble protein; Western blots, A $\beta$ ELISAs, and dot blots were performed as previously described (Blurton-Jones et al., 2009). Coimmunoprecipitation was performed using PSD-95 antibody (Abcam) and DynaBeads (Invitrogen).

Immunofluorescence and confocal microscopy. Fluorescent labeling followed standard protocols (Blurton-Jones et al., 2009). Primary antibodies included: 6E10 (Signet), CT-20 (Calbiochem), Tau: HT7 (Innogenetics), PHF-1 (gift from P. Davies, Albert Einstein College, Yeshiva University, New York, NY), $\beta$-actin (Sigma), and GAPDH (Santa Cruz Biotechnology). Primary antibodies were applied overnight at $4^{\circ} \mathrm{C}$ and detected with appropriate AlexaFluor-conjugated secondary antibodies (Invitrogen). Specificity of all primary antibodies was confirmed by Western blot and by omission of primary antibody in immunofluorescent labeling. Sections were visualized using a Bio-Rad 2100 confocal system and lambda-strobing mode (Bio-Rad Laboratories).

Statistical analysis. Comparisons between multiple groups were performed using ANOVA followed by Fischer's PLSD post hoc tests. Analysis of MWM acquisition was examined via repeated-measures ANOVA. Groups were considered significantly different when $p<0.05$ for both the ANOVA and post hoc comparisons. Comparisons between two groups used unpaired Student's $t$ test. All statistical analysis was performed using Statview5.01 software.

\section{Results}

ArcTau mice develop age-related deficits in learning and memory and increasing pathology

To test whether ArcTau mice develop age-related cognitive dysfunction, transgenic and control mice were tested in the MWM at 
6, 12, and 18 months of age. At 6 months, ArcTau mice learn normally during MWM acquisition, but exhibit memory deficits for the platform location during probe trial testing (data not shown). By 12 months, cognition further deteriorates as ArcTau mice exhibit not only probe trial deficits but also take significantly longer to learn the platform location during MWM acquisition versus wild-type (WT) mice (Fig. $1 D, E$ ). These impairments become even further pronounced by 18 months (data not shown). Importantly, these differences cannot be attributed to motor deficits, as the swim speeds of both ArcTau and WT mice are equivalent (data not shown), and there are no differences found in Rotarod testing (Fig. $1 B$ ). Thus, ArcTau mice develop progressive age-related impairments in learning and memory, recapitulating an important feature of $\mathrm{AD}$ pathogenesis.

Although we deliberately chose to express low levels $(\sim 2$ fold) of APP in the ArcTau model (Fig. 1C), these mice nevertheless develop age-related deficits in learning and memory. Given the importance of soluble $\mathrm{A} \beta$ oligomers in cognitive decline, we next examined these species using conformational-dependent antibodies (Kayed et al., 2003, 2007; Lesné et al., 2006). The A11 antibody labels prefibrillar oligomers, whereas OC antibody specifically labels conformationally distinct fibrillar oligomers (Glabe, 2008). Fibrillar oligomers are identified by 6 months and show a dramatic increase at 12 months, corresponding with the time point that significant learning and memory deficits are first observed (Fig. $1 F, G$ ). Intraneuronal $\mathrm{A} \beta$, identified by colabeling with $6 \mathrm{E} 10(\mathrm{~A} \beta / \mathrm{APP})$ and a $\mathrm{C}$-terminal-specific APP antibody, is also observed by 6 months within CA1 neurons, the basolateral nucleus of the amygdala, and cortical pyramidal neurons (Fig. $1 H-J)$. At the same age, ArcTau mice exhibit extensive somatodendritic tau pathology throughout the hippocampus, subiculum, amygdala, and cortex, despite the fact that the mice only harbor a wild-type human tau transgene (Fig. $1 K-M$ ). As ArcTau mice age, intraneuronal $\mathrm{A} \beta$ pathology increases, yet extracellular $\mathrm{A} \beta$ deposition does not occur until 18 months (Fig. $1 \mathrm{~N}, O$ ). Interestingly, the small $\mathrm{A} \beta$ plaques observed in aged mice are diffuse, thioflavin-negative, and appear similar to the donut-shaped plaques reported in human patients harboring the Arctic mutation (Basun et al., 2008). This result is consistent with recent findings demonstrating that OC-positive fibrillar oligomers do not seed fibrillar plaque formation (Wu et al., 2010). Biochemical analyses confirm the diffuse soluble nature of these plaques, as detergent-insoluble $\mathrm{A} \beta$ is undetectable at any of the ages examined (data not shown). Notably, wild-type tau pathology also increases with age, including the appearance of PHF-1-positive neurons within the hippocampus and subiculum of 18-monthold mice (Fig. 1P,Q). Interestingly, Gallyas-positive insoluble aggregates and neuronal loss are not observed in ArcTau mice, even after 20 months (data not shown). This is consistent with previous wild-type tau models that overexpress human tau in the presence of endogenous mouse tau (Duff et al., 2000; Zhang et al., 2004); however, wild-type human tau can form paired-helical filaments and neurofibrillary tangles in a transgenic model that lacks endogenous tau (Andorfer et al., 2003), suggesting that the presence of murine tau may modulate the development of Gallyas-positive neurofibrillary tangles.

\section{Partial BACE deletion reduces soluble $\mathrm{A} \beta$ and prevents} ArcTau learning and memory impairments

Genetic reduction of BACE1, the primary enzyme responsible for amyloidogenic cleavage of APP, was achieved by crossing hemizygous ArcTau mice with heterozygous BACE knock-outs. Interestingly, ArcTau/BACE ${ }^{+/-}$mice perform as well as WT/
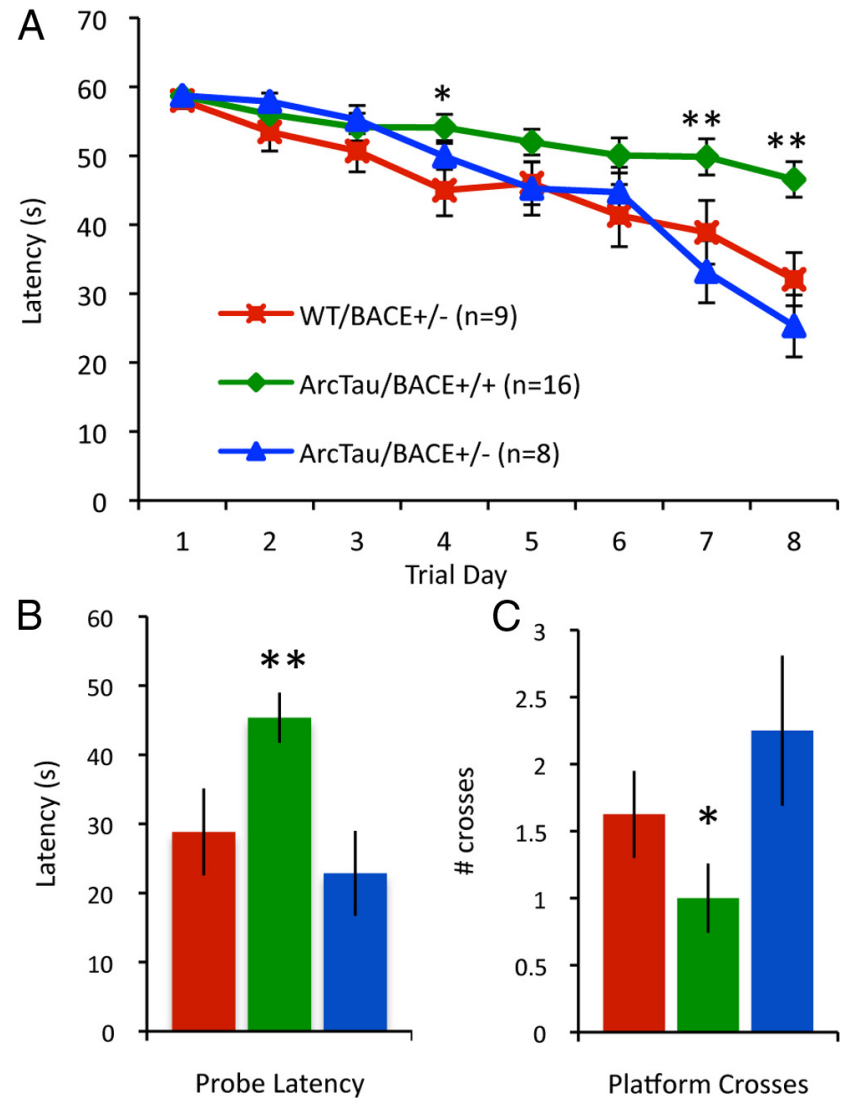

Figure 2. Partial genetic deletion of BACE prevents learning and memory impairments. $A_{t}$ Fifteen-month-old ArCTau, ArcTau/BACE ${ }^{+/-}$, and WT/BACE ${ }^{+/-}$were trained in Morris water maze for $8 \mathrm{~d}$. ArcTau/BACE ${ }^{+/-}$performed similarly to WT/BACE ${ }^{+/-}$(cognitively normal), while $\operatorname{ArCTau} / B A C E^{+/+}$displayed significant learning deficits on days 4,7 , and $8 . B, C$, In the $24 \mathrm{~h}$ probe trial, ArcTau/BACE ${ }^{+/+}$mice took almost twice as long to reach the former platform location and also crossed this area significantly fewer times than ArCTau/BACE ${ }^{+/-}$and WT/ $B A C E^{+/-}$mice. Error bars represent \pm SEM; ${ }^{*} p<0.05{ }^{* *} p<0.01$.

$B A C E^{+/-}$in MWM at 15 months. $B A C E^{+/-}$mice have normal cognition (Roberds et al., 2001). In contrast, ArcTau littermates with physiological BACE expression (ArcTau/BACE ${ }^{+/+}$) exhibit significant learning and memory deficits (Fig. 2). The fact that only a partial reduction in BACE is sufficient to prevent cognitive deficits indicates that BACE inhibitors could be effective therapeutics for memory impairment.

We next investigated the effects of BACE reduction on soluble $\mathrm{A} \beta$. As expected, soluble $\mathrm{A} \beta$ levels are partially decreased by heterozygous BACE deletion ( $p=0.0002$; Fig. $3 E$ ), consistent with previous studies (McConlogue et al., 2007), while APP expression remains unchanged (Fig. $3 A, B$ ). Interestingly, levels of $\mathrm{A} \beta$ oligomers, particularly OC-positive fibrillar oligomers, are also significantly decreased in the $\operatorname{ArcTau} / B A C E^{+/-}$compared with $A r c T a u / B A C E^{+/+}(p=0.01$; Fig. $3 C, D)$. Together, these data provide evidence that soluble $A \beta$ oligomers play an important role in ArcTau mice cognitive impairment, as reduction in these species restores cognition to wild-type levels.

\section{Reduction of soluble $A \beta$ prevents mislocalization and accumulation of wild-type human tau pathology} Because we demonstrated that partial BACE reduction was sufficient to reduce soluble $\mathrm{A} \beta$, we next sought to investigate whether there was a concomitant decrease in wild-type tau pathology. Biochemical analysis revealed significant reductions in total soluble tau levels (HT7) as well as levels of PHF-1 hyperphosphory- 
lated tau (pS396/S404; Fig. 4A,B). We did not detect differences in levels of murine phosphorylated tau at any of the epitopes examined. Levels of several other human tau phosphorylation epitopes and activity of the major tau kinases, GSK3 $\beta$ and Cdk5, remain unchanged (Fig. $4 D, E$ ), suggesting that soluble oligomeric forms of $\mathrm{A} \beta$ likely facilitate tau pathology by inhibiting tau degradation, rather than enhancing tau phosphorylation. Additionally, immunohistochemistry analysis demonstrated a lack of somatodendritic localized tau in ArcTau/BACE ${ }^{+/-}$compared with $A r c T a u / B A C E^{+/+}$, indicating that $\mathrm{BACE}$ reduction largely prevents tau mislocalization (Fig. 4C). To examine the potential mechanisms by which $\mathrm{A} \beta$ may facilitate tau accumulation, we probed for several markers in the proteasome and autophagic degradative pathways. The slight increase in the tau E3 ligase $\mathrm{C}$ terminus of heat shock protein 70 interacting protein (CHIP) and decrease in ubiquitinated proteins in $\mathrm{ArCTau} / \mathrm{BACE}^{+/-}$mice suggest that there may be improved proteasomal function compared with ArcTaul $B A C E^{+/+}$mice, but these trends are not statistically significant. LC3-I is significantly increased in both ArcTau/BACE genotypes compared with wild-type, but no further differences are detected between ArcTau/BACE ${ }^{+/+}$and ArcTau/BACE ${ }^{+/-}$(Fig. $4 F, G)$. Additionally, no differences in levels of the presynaptic marker synaptophysin were detected in any genotype, suggesting that altered synaptic number does not contribute to the observed cognitive differences.

To further probe for the mechanisms responsible for the robust cognitive differences observed in ArcTau mice with BACE reduction, we performed coimmunoprecipitation with the presynaptic scaffolding protein, PSD-95. Importantly, we found marked differences in levels of human tau, Fyn kinase, and NR2B between all three genotypes, while levels of Homer remained unchanged (Fig. $4 F, G$ ). These data fit well with previous findings that suggest that dendritic mislocalization of tau and Fyn kinase can stabilize the interaction between PSD-95 and NMDA receptor complexes (Ittner et al., 2010), possibly rendering the synapse more susceptible to $\mathrm{A} \beta$-dependent excitotoxicity.

\section{Discussion}

We and others previously used mutant forms of tau to study the interaction between $\mathrm{A} \beta$ and tau (Götz et al., 2001; Lewis et al., 2001; Oddo et al., 2003, 2004). Although such analyses have revealed important information about the potential relationship between $A \beta$ and tau, some of these interactions likely differ depending on whether mutant or wild-type tau is examined. An important unresolved question is therefore whether $\mathrm{A} \beta$ can facilitate wild-type tau in vivo. ArcTau mice develop increasing $\mathrm{A} \beta$ oligomer and wild-type human tau pathology, leading to progressive age-related impairments in cognition. More importantly, partial reduction in BACE decreases not only soluble $\mathrm{A} \beta$ levels, but also tau pathology and cognitive decline.

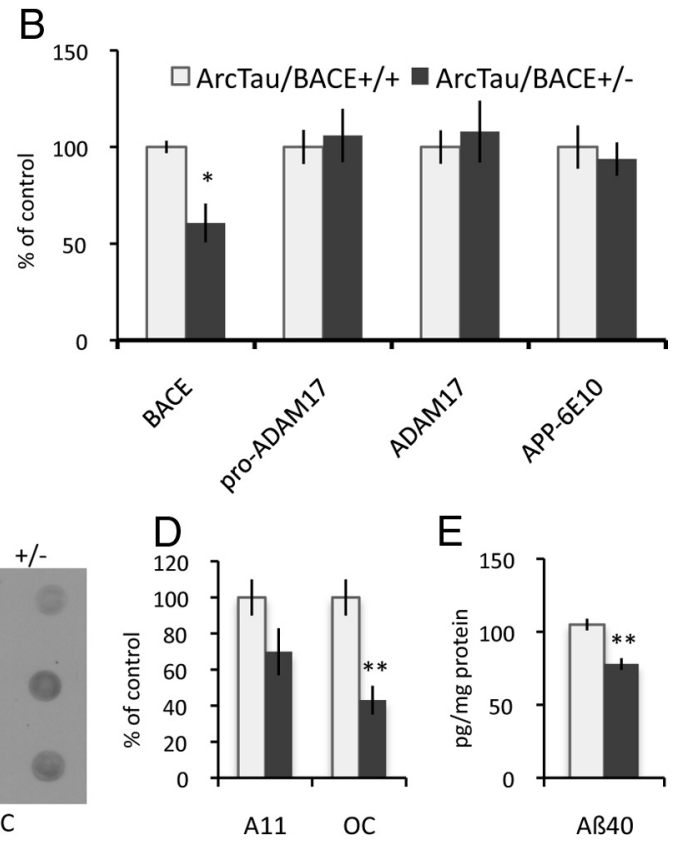

Figure 3. Partial genetic reduction of $B A C E$ reduces Arctic $A \beta$ and prefibrillar oligomeric $A \beta$. $A$, BACE levels are significantly decreased in ArcTau/BACE ${ }^{+/-}$compared with ArcTau/BACE ${ }^{+/+}$mice, while APP and $\alpha$-secretase ADAM17 levels are unchanged. Quntitation of the Western blots in $\boldsymbol{A}$ by densitometric analysis, shown as percentage of control. $\boldsymbol{C}, \boldsymbol{D}$, Dot blots from ArcTau detected by $A 11$ do not vary. $E$, Levels of $A \beta 40$ are significantly decreased in $A r C T a u / B A C E^{+-}$mice, measured by standard ELISA methods. $A \beta 42$ is undetectable in this model. $N=4-5$ per group. Error bars represent $\pm S E M ;{ }^{*} p<0.05,{ }^{* *} p<0.01$.

In contrast to previous transgenic models using the Arctic mutation, we chose to microinject a low copy number of the Arctic/Swedish APP construct to investigate the effects of near physiological levels of $\mathrm{A} \beta$, pertinent to early events in $\mathrm{AD}$ (Cheng et al., 2004; Lord et al., 2006). The aggressive development of insoluble $\mathrm{A} \beta$ pathology in these prior models is useful for certain studies but makes it difficult to separate the contributions of soluble versus insoluble $\mathrm{A} \beta$. ArcTau mice do not form insoluble thioflavin-positive $A \beta$ plaques; thus, our data demonstrate that soluble $\mathrm{A} \beta$ can drive the development of cognitive dysfunction. Recent clinical data support our findings by showing low Pittsburgh compound B retention in early-onset familial AD patients carrying the Arctic mutation, despite severe cognitive deficits (Schöll et al., 2012). Additionally, our experiments demonstrate that low levels of soluble $A \beta$ oligomers can profoundly influence the development of wild-type human tau pathology.

Notably, BACE reduction resulted in a specific decrease in soluble $\mathrm{A} \beta$ levels and $\mathrm{OC}+$ oligomers. In turn, total tau and PHF-1 hyperphosphorylated tau were also significantly reduced. It remains unclear precisely how tau is reduced in ArcTau/ $B A C E^{+/-}$mice, although experiments in other models suggest that $\mathrm{A} \beta$-mediated proteasome impairment is likely involved (Oddo et al., 2008; Tseng et al., 2008). Interestingly, we observed a trend for increased expression of the tau E3 ligase, CHIP, and decreased levels of ubiquitinated proteins in ArcTau/BACE ${ }^{+/-}$ mice, suggesting that altered proteasomal function may be involved. However, future studies will be needed to fully decipher the mechanism by which partial BACE deletion reduces tau.

Our examination of synaptic proteins suggest that the cognitive impairment in ArcTau mice is likely due to the accumulation of tau in the synapse and the enhancement of NMDA receptor retention by PSD-95. Notably, each of these findings is partially mitigated by BACE reduction and cognitive function is corre- 
A

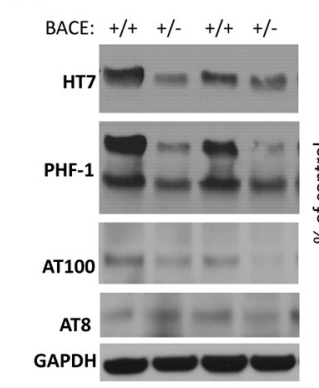

B

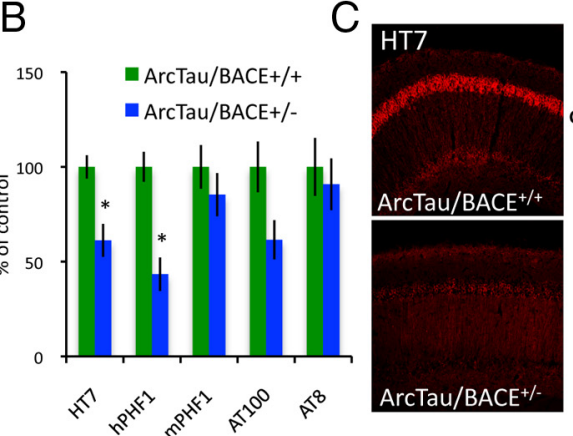

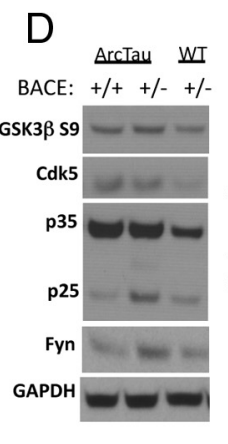

$E$

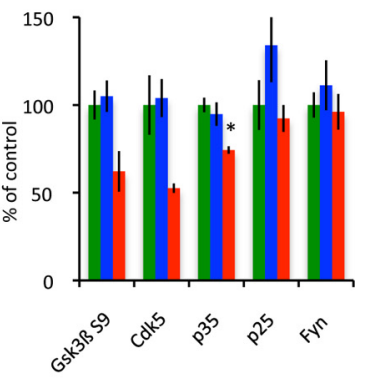

$\mathrm{F}$

G

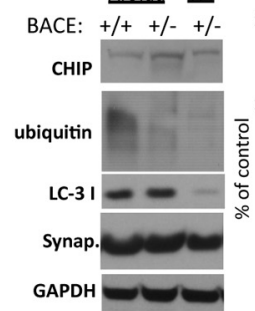

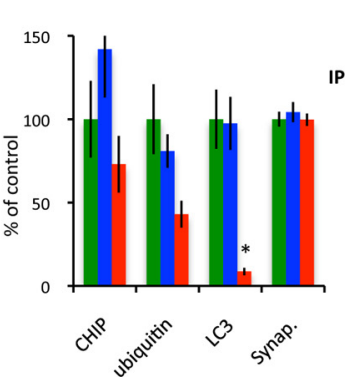

$\mathrm{H}$
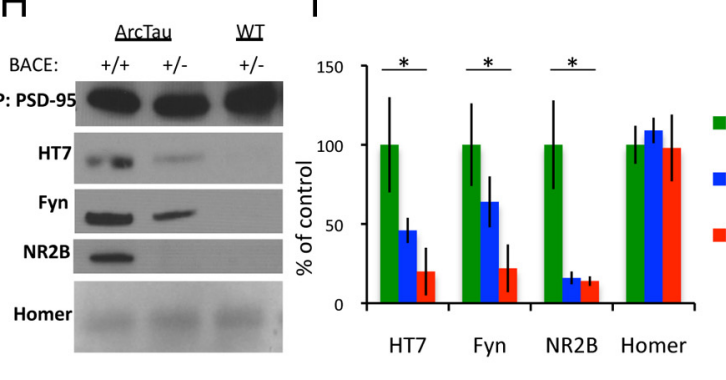

- ArcTau/BACE+/+

- ArcTau/BACE+/-

- WT/BACE+/-

Figure 4. Reduction of soluble $A \beta$ prevents mislocalization and accumulation of wild-type tau. $\boldsymbol{A}, \boldsymbol{B}$, Total tau levels and tau phosphorylated at pS396/S404 are decreased in ArcTau/BACE ${ }^{+/-}$ mice, whereas other phospho-tau epitopes remain unchanged. $C$, Somatodendritic wild-type human tau is abundant in ArcTau/ BACE ${ }^{+/+}$mice, while barely detectable in the somatodendritic compartments of $A r C T a u / B A C E^{+/-}$mice. D, E, Western blots probing for alterations in kinase levels or activity show no differences between $\operatorname{ArcTau} / B A C E^{+/+}$and $A r c T a u / B A C E{ }^{+/-}$mice. $F, G$, There are no statistically significant differences in proteasome activity, as evidenced by levels of CHIP and ubiquitinated proteins, or autophagy (LC3) between ${\operatorname{ArcTau} / B A C E^{+/+}}_{\text {and }}{\operatorname{ArcTau} / B A C E^{+/-}}^{-}$ mice, although there appears to be a buildup of autophagosomes in both ArcTau genotypes compared with wild-type. $\boldsymbol{H}, \boldsymbol{I}$, Interestingly, coimmunoprecipitation reveals dramatic decreases in the association between PSD-95 and tau, Fyn kinase, and the NR2B subunit of the NMDA receptor in ArcTau/BACE ${ }^{+/-}$versus ArcTau/BACE ${ }^{+/+}$mice. $N=4-5$ per group; ${ }^{*} p<0.05$ compared with $^{-1}$ ArCTau/BACE ${ }^{+/+}$mice. Error bars represent \pm SEM.

spondingly improved. Together, our findings demonstrate that soluble $\mathrm{A} \beta$ oligomers drive the development of both cognitive dysfunction and tau pathology. Curiously, a recent study reported that BACE knock-out in 3xTg-AD mice reduced $\mathrm{A} \beta$ levels without affecting tau immunoreactivity (Winton et al., 2011). Although biochemical analyses were not included, the conclusions of Winton and colleagues (2011) contradicts several prior studies demonstrating that immunological or genetic reduction of $\mathrm{A} \beta$ reduces tau pathology in $3 \mathrm{xTg}-\mathrm{AD}$ and other $\mathrm{AD}$ mouse models (Götz et al., 2001; Oddo et al., 2004, 2008; Pérez et al., 2005). Our current study, using a similar approach to Winton et al. (2011), also contradicts their findings, revealing that reduction of soluble $\mathrm{A} \beta$ reduces the development of wild-type human tau pathology. Our data further support the notion that $\mathrm{A} \beta$ can drive tau pathogenesis. Importantly, the current study also clearly demonstrates that soluble $A \beta$ is critical for this process. Thus, early targeting of soluble $\mathrm{A} \beta$ oligomers may provide an effective method to not only improve memory but also prevent taumediated neuronal dysfunction in $\mathrm{AD}$.

\section{References}

Andorfer C, Kress Y, Espinoza M, de Silva R, Tucker KL, Barde YA, Duff K, Davies P (2003) Hyperphosphorylation and aggregation of tau in mice expressing normal human tau isoforms. J Neurochem 86:582-590. CrossRef Medline

Basun H, Bogdanovic N, Ingelsson M, Almkvist O, Näslund J, Axelman K, Bird TD, Nochlin D, Schellenberg GD, Wahlund LO, Lannfelt L (2008) Clinical and neuropathological features of the arctic APP gene mutation causing early-onset Alzheimer disease. Arch Neurol 65:499-505. CrossRef Medline

Billings LM, Oddo S, Green KN, McGaugh JL, LaFerla FM (2005) Intraneuronal Abeta causes the onset of early Alzheimer's disease-related cognitive deficits in transgenic mice. Neuron 45:675-688. CrossRef Medline
Blurton-Jones M, Kitazawa M, Martinez-Coria H, Castello NA, Müller FJ, Loring JF, Yamasaki TR, Poon WW, Green KN, LaFerla FM (2009) Neural stem cells improve cognition via BDNF in a transgenic model of Alzheimer disease. Proc Natl Acad Sci U S A 106:13594-13599. CrossRef Medline

Cheng IH, Palop JJ, Esposito LA, Bien-Ly N, Yan F, Mucke L (2004) Aggressive amyloidosis in mice expressing human amyloid peptides with the Arctic mutation. Nat Med 10:1190-1192. CrossRef Medline

Deshpande A, Mina E, Glabe C, Busciglio J (2006) Different conformations of amyloid beta induce neurotoxicity by distinct mechanisms in human cortical neurons. J Neurosci 26:6011-6018. CrossRef Medline

Duff K, Knight H, Refolo LM, Sanders S, Yu X, Picciano M, Malester B, Hutton M, Adamson J, Goedert M, Burki K, Davies P (2000) Characterization of pathology in transgenic mice over-expressing human genomic and cDNA tau transgenes. Neurobiol Dis 7:87-98. CrossRef Medline

Glabe CG (2008) Structural classification of toxic amyloid oligomers. J Biol Chem 283:29639-29643. CrossRef Medline

Götz J, Chen F, van Dorpe J, Nitsch RM (2001) Formation of neurofibrillary tangles in P3011 tau transgenic mice induced by Abeta 42 fibrils. Science 293:1491-1495. CrossRef Medline

Ittner LM, Ke YD, Delerue F, Bi M, Gladbach A, van Eersel J, Wölfing H, Chieng BC, Christie MJ, Napier IA, Eckert A, Staufenbiel M, Hardeman E, Götz J (2010) Dendritic function of tau mediates amyloid-beta toxicity in Alzheimer's disease mouse models. Cell 142:387-397. CrossRef Medline

Kayed R, Head E, Thompson JL, McIntire TM, Milton SC, Cotman CW, Glabe CG (2003) Common structure of soluble amyloid oligomers implies common mechanism of pathogenesis. Science 300:486-489. CrossRef Medline

Kayed R, Head E, Sarsoza F, Saing T, Cotman CW, Necula M, Margol L, Wu J, Breydo L, Thompson JL, Rasool S, Gurlo T, Butler P, Glabe CG (2007) Fibril specific, conformation dependent antibodies recognize a generic epitope common to amyloid fibrils and fibrillar oligomers that is absent in prefibrillar oligomers. Mol Neurodegener 2:18. CrossRef Medline

Lacor PN, Buniel MC, Chang L, Fernandez SJ, Gong Y, Viola KL, Lambert MP, Velasco PT, Bigio EH, Finch CE, Krafft GA, Klein WL (2004) Syn- 
aptic targeting by Alzheimer's-related amyloid beta oligomers. J Neurosci 24:10191-10200. CrossRef Medline

Lesné S, Koh MT, Kotilinek L, Kayed R, Glabe CG, Yang A, Gallagher M, Ashe $\mathrm{KH}$ (2006) A specific amyloid-beta protein assembly in the brain impairs memory. Nature 440:352-357. CrossRef Medline

Lewis J, Dickson DW, Lin WL, Chisholm L, Corral A, Jones G, Yen SH, Sahara N, Skipper L, Yager D, Eckman C, Hardy J, Hutton M, McGowan E (2001) Enhanced neurofibrillary degeneration in transgenic mice expressing mutant tau and APP. Science 293:1487-1491. CrossRef Medline

Lord A, Kalimo H, Eckman C, Zhang XQ, Lannfelt L, Nilsson LN (2006) The Arctic Alzheimer mutation facilitates early intraneuronal Abeta aggregation and senile plaque formation in transgenic mice. Neurobiol Aging 27:67-77. CrossRef Medline

McConlogue L, Buttini M, Anderson JP, Brigham EF, Chen KS, Freedman SB, Games D, Johnson-Wood K, Lee M, Zeller M, Liu W, Motter R, Sinha S (2007) Partial reduction of BACE1 has dramatic effects on Alzheimer plaque and synaptic pathology in APP transgenic mice. J Biol Chem 282: 26326-26334. CrossRef Medline

McLean CA, Cherny RA, Fraser FW, Fuller SJ, Smith MJ, Beyreuther K, Bush AI, Masters CL (1999) Soluble pool of Abeta amyloid as a determinant of severity of neurodegeneration in Alzheimer's disease. Ann Neurol 46: 860-866. CrossRef Medline

Näslund J, Haroutunian V, Mohs R, Davis KL, Davies P, Greengard P, Buxbaum JD (2000) Correlation between elevated levels of amyloid betapeptide in the brain and cognitive decline. JAMA 283:1571-1577. CrossRef Medline

Oddo S, Caccamo A, Shepherd JD, Murphy MP, Golde TE, Kayed R, Metherate R, Mattson MP, Akbari Y, LaFerla FM (2003) Triple-transgenic model of Alzheimer's disease with plaques and tangles: intracellular Abeta and synaptic dysfunction. Neuron 39:409-421. CrossRef Medline

Oddo S, Billings L, Kesslak JP, Cribbs DH, LaFerla FM (2004) Abeta immunotherapy leads to clearance of early, but not late, hyperphosphorylated tau aggregates via the proteasome. Neuron 43:321-332. CrossRef Medline

Oddo S, Caccamo A, Tseng B, Cheng D, Vasilevko V, Cribbs DH, LaFerla FM (2008) Blocking Abeta 42 accumulation delays the onset and progression of tau pathology via the $\mathrm{C}$ terminus of heat shock protein70-interacting protein: a mechanistic link between Abeta and tau pathology. J Neurosci 28:12163-12175. CrossRef Medline
Pérez M, Ribe E, Rubio A, Lim F, Morán MA, Ramos PG, Ferrer I, Isla MT, Avila J (2005) Characterization of a double (amyloid precursor protein-tau) transgenic: tau phosphorylation and aggregation. Neuroscience 130:339-347. CrossRef Medline

Querfurth HW, LaFerla FM (2010) Alzheimer's disease. N Engl J Med 362: 329-344. CrossRef Medline

Roberds SL, Anderson J, Basi G, Bienkowski MJ, Branstetter DG, Chen KS, Freedman SB, Frigon NL, Games D, Hu K, Johnson-Wood K, Kappenman KE, Kawabe TT, Kola I, Kuehn R, Lee M, Liu W, Motter R, Nichols NF, Power M, et al. (2001) BACE knockout mice are healthy despite lacking the primary beta-secretase activity in brain: implications for Alzheimer's disease therapeutics. Hum Mol Genet 10:1317-1324. CrossRef Medline

Schöll M, Wall A, Thordardottir S, Ferreira D, Bogdanovic N, Långström B, Almkvist O, Graff C, Nordberg A (2012) Low PiB PET retention in presence of pathologic CSF biomarkers in Arctic APP mutation carriers. Neurology 79:229-236. CrossRef Medline

Tseng BP, Green KN, Chan JL, Blurton-Jones M, LaFerla FM (2008) Abeta inhibits the proteasome and enhances amyloid and tau accumulation. Neurobiol Aging 29:1607-1618. CrossRef Medline

Winton MJ, Lee EB, Sun E, Wong MM, Leight S, Zhang B, Trojanowski JQ, Lee VM (2011) Intraneuronal APP, not free Abeta peptides in 3xTg-AD mice: implications for tau versus Abeta-mediated Alzheimer neurodegeneration. J Neurosci 31:7691-7699. CrossRef Medline

Wu JW, Breydo L, Isas JM, Lee J, Kuznetsov YG, Langen R, Glabe C (2010) Fibrillar oligomers nucleate the oligomerization of monomeric amyloid beta but do not seed fibril formation. J Biol Chem 285:6071-6079. CrossRef Medline

Zempel H, Thies E, Mandelkow E, Mandelkow EM (2010) Abeta oligomers cause localized $\mathrm{Ca}(2+)$ elevation, missorting of endogenous tau into dendrites, tau phosphorylation, and destruction of microtubules and spines. J Neurosci 30:11938-11950. CrossRef Medline

Zhang B, Higuchi M, Yoshiyama Y, Ishihara T, Forman MS, Martinez D, Joyce S, Trojanowski JQ, Lee VM (2004) Retarded axonal transport of R406W mutant tau in transgenic mice with a neurodegenerative tauopathy. J Neurosci 24:4657-4667. CrossRef Medline 